\title{
Dampak Strategi Bisnis terhadap Penghindaran Pajak
}

\author{
Sekar Akrom Faradiza ${ }^{\mathrm{a}, *}$ \\ a Program Studi Akuntansi, Universitas Teknologi Yogyakarta, sekar.akrom@uty.ac.id, Indonesia
}

\begin{abstract}
In carrying out business processes of a company, managers must make decisions related to business strategies. The strategy chosen by the company can be one of the typologies according to Miles \& Snow namely the prospector, defender, analyzer and reactor. The strategy chosen by the company will affect all activities in the company including tax activities inherent in business activities so that any decisions made by managers have consequences on tax, one of which is tax avoidance. This study aims to examine the impact of the strategy on tax avoidance. This research used manufacturing company that has been listed on the Indonesia Stock Exchange from 2010 to 2016 and Independent sample t-test and Mann Whitney U test is used to data analyze. The results showed that companies with prospector strategies were more likely to carry out tax avoidance than defender. In addition, the activities of tax aggressiveness through investment in tax haven countries are mostly carried out by companies with a defender strategy.
\end{abstract}

Keywords: tax avoidance, tax aggressive, strategy, prospector, defender

\section{Pendahuluan}

Wajib pajak selalu memandang pajak sebagai suatu beban, yaitu berupa pengalihan sumber daya dari sektor bisnis ke sektor publik atau pemerintah yang akan mengakibatkan berkurangnya daya beli atau kemampuan belanja wajib pajak. Sehingga wajib pajak selalu berupaya untuk mengurangi beban pajak dengan melakukan manajemen pajak atau mengarahkan proses bisnis dan keputusan bisnis yang menguntungkan dilihat dari aspek pajak. Pada perusahaan publik, para pemegang saham selalu menginginkan agar manajer mengambil keputusan bisnis yang sejalan dengan kepentingan mereka, termasuk keputusan terkait pajak, para pemegang saham menghendaki agar keputusan tersebut dapat meningkatkan nilai perusahaan dan kekayaan setelah pajak.

Penghindaran pajak adalah suatu skema transaksi yang ditujukan untuk meminimalkan beban pajak dengan memanfaatkan kelemahan (loopholes) ketentuan-ketentuan perpajakan suatu negara. Di Indonesia, terdapat dua upaya yang dapat ditempuh oleh wajib pajak untuk mempengaruhi besarnya pajak yang harus dibayar yaitu yang dilakukan secara legal (melalui perencanaan pajak efektif atau penghindaran pajak atau tax avoidance) dan secara ilegal (melalui pengelakan pajak atau tax evasion). Penghindaran pajak secara legal dapat dilakukan dengan cara menahan diri, pindah lokasi dan memanfaatkan celah hukum agar terhindar dari pengenaan pajak. Sedangkan di negara lain contohnya di Amerika Serikat, skema penghindaran pajak terbagi menjadi dua yaitu penghindaran pajak yang diperbolehkan (acceptable tax avoidance) dan penghindaran pajak yang tidak diperbolehkan (unacceptable tax avoidance). Unacceptable tax avoidance ini lah yang dikategorikan sebagai penghindaran pajak yang agresif. Di Indonesia belum ada undang-undang yang mengatur unacceptable tax avoidance, sehingga dalam prakteknya sering terjadi perbedaan penafsiran antara wajib pajak dan aparatur pajak.

Dyreng, Hanlon, \& Maydew (2010) mendefinisikan penghindaran pajak yaitu pengurangan pajak eksplisit yang merepresentasikan serangkaian strategi perencanaan pajak mulai dari manajemen pajak (tax management), perencanaan pajak (tax planning), pajak agresif (tax aggressive), tax evasion dan tax

\footnotetext{
*Corresponding author. E-mail: sekar.akrom@uty.ac.id
} 
sheltering. Penghindaran pajak selalu diartikan sebagai kegiatan legal. Namun pertanyaan yang saat ini muncul adalah apakah penghindaran pajak atau tax avoidance selalu legal. Penghindaran pajak dapat saja dikategorikan sebagai kegiatan ilegal apabila transaksi yang dilakukan semata-mata untuk tujuan penghindaran pajak atau transaksi tersebut tidak mempunyai usaha yang baik. Penghindaran pajak dilakukan sebagai akibat dari suatu kesalahan alokasi yang terjadi di dunia nyata, kemerosotan etika bisnis, hilangnya independensi auditor dan interfensi dengan suatu sistem kendali.

Untuk mengawali proses bisnis dari suatu perusahaan, manajer terlebih dahulu harus mengambil keputusan terkait strategis bisnis. Untuk mencapai kinerja melalui keunggulan daya saing di tengah ketidakpastian lingkungan maka perusahaan memerlukan roadmap dan strategi yang tepat. Beragam penelitian strategi bisnis mengacu pada dua model strategi yaitu: (1) tipologi strategi Miles dan Snow, dan (2) strategi bersaing generik milik Porter. Dari dua strategi tersebut, tipologi Miles dan Snow lah yang banyak digunakan. Strategi tersebut adalah (1) prospector yang menitikberatkan pada productmarket innovation, (2) defender yang menekankan pada cost control dan efficiency, (3) analyzer yang berfokus pada keduanya baik product-market innovation maupun cost efficiency, dan (4) reactor. Tipologi orientasi strategi bisnis tersebut memiliki karakteristik dan perilaku yang berbeda-beda (Tjahjad, 2011).

Strategi yang dipilih oleh perusahaan akan mempengaruhi seluruh aktivitas dalam perusahaan karena seluruh keputusan yang diambil oleh manajer harus sejalan dengan strategi bisnis. Termasuk aktivitas pajak yang melekat dalam aktivitas bisnis sehingga setiap keputusan bisnis yang dibuat oleh manajer memiliki konsekuensi pada pajak. Dengan menggunakan teori strategi bisnis yang dikemukakan oleh Miles \& Snow (1978), penelitian ini akan menguji hubungan antara strategi perusahaan dan strategi perencanaan pajak yang dilakukan. Higgins et al. (2015) menyatakan bahwa strategi bisnis perusahaan berpengaruh terhadap strategi penghindaran pajak.

Penghindaran pajak oleh suatu perusahaan dilakukan melalui kebijakan yang diambil oleh pemimpin perusahaan itu sendiri, dan setiap perusahaan akan memiliki cara-cara yang berbeda karena memiliki karakter pemimpin yang berbedabeda. Seorang pemimpin perusahaan bisa saja memiliki karakter risk taker ataupun risk averter yang tercermin dari besar kecilnya risiko perusahaan serta sesuai dengan strategi bisnis yang dipilih oleh perusahaan (Cahyono dkk, 2016).

Beberapa penelitian terkait penghindaran pajak telah banyak digunakan dengan menggunakan pengukuran tunggal antara lain dengan effective tax rate (ETR), book tax difference (BTD), abnormal BTD serta permanent difference (contohnya Dyreng et al., 2010; Graham et al., 2014; Higgins et al., 2015). Penelitian-penelitian sebelumnya juga lebih banyak melihat faktor-faktor pendorong perilaku penghindaran pajak dari aspek finansial. Berbeda dengan penelitian-penelitian yang telah ada sebelumnya, penelitian ini akan menggunakan 3 indikator dari penghindaran pajak yaitu book effective tax rate (Book ETR), cash effective tax rate (Cash ETR) dan permanent book-tax difference (PERMDIFF) serta mengaitkan perilaku penghindaran pajak ini dengan faktor non finansial yaitu strategi bisnis yang dijalankan oleh perusahaan. Selain itu penelitian ini juga akan mengukur agresivitas pajak dengan menggunakan proksi tax haven yang menunjukkan bahwa sebagian perusahaan berupaya untuk menghindari pajak dengan berinvestasi di negara-negara dengan tarif pajak yang lebih rendah.

Berdasarkan uraian latar belakang tersebut maka penelitian ini akan melihat bagaimana tindakan penghindaran pajak dan agresivitas pajak yang dilakukan oleh perusahaan dengan membedakan perusahaan yang menerapkan strategi berdasarkan tipologi strategi Miles dan Snow. Penelitian ini memiliki kontribusi bagi para investor dalam menilai kualitas laba dan tingkat agresivitas pajak ketika mengambil keputusan investasi. Berdasarkan laporan keuangan dan informasi yang diterima, selanjutnya investor dapat melakukan penilaian lebih dalam apakah perusahaan melakukan tindakan-tindakan yang mengarah kepada agresivitas pajak yang pada akhirnya akan berdampak kepada perusahaan dan investor. Selain itu penelitian ini juga akan berkontribusi dengan memberi masukan kepada regulator dalam hal pengaturan cara-cara penghindaran pajak agar tidak menimbulkan kesalahan persepsi dan penafsiran undang-undang oleh para wajib pajak yang berbeda dengan maksud pembuatnya.

\section{Tinjauan Literatur}

\section{Penghindaran pajak}

Upaya dalam melakukan perencanaan pajak secara legal dapat dilakukan melalui manajemen pajak. 
Namun perlu diperhatikan bahwa legalitas dari perencanaan pajak tergantung dari instrumen atau cara yang dipakai. Legal atau tidaknya tindakan perencanaan pajak yang dilakukan dapat diketahui secara pasti setelah ada putusan pengadilan. Perencanaan pajak merupakan langkah awal dari manajemen pajak. Jika tujuan perencanaan pajak adalah untuk merekayasa agar beban pajak (tax burdens) rendah dengan memanfaatkan peraturan yang ada tapi berbeda dengan tujuan pembuat undangundang maka perencanaan pajak tersebut sama dengan penghindaran pajak (tax avoidance).

Biasanya dalam melakukan penghindaran pajak perusahaan melakukan strategi-strategi atau cara-cara yang legal sesuai dengan aturan undang-undang yang berlaku, namun dilakukan dengan memanfaatkan halhal yang sifatnya ambigu sehingga dalam hal ini wajib pajak memanfaatkan celah-celah yang ditimbulkan oleh adanya ambiguitas dalam undang-undang perpajakan. Strategi penghematan pajak tersebut disebut juga sebagai suatu strategi pajak yang agresif. Ada tahapan atau langkah yang akan dilakukan oleh perusahaan dalam meminimalkan pajak, yaitu:

1. Perusahaan berusaha untuk menghindari pajak baik secara legal maupun ilegal.

2. Mengurangi beban pajak seminimal mungkin baik secara legal maupun ilegal.

3. Apabila kedua langkah sebelumnya tidak dapat dilakukan maka wajib pajak akan membayar pajak tersebut.

Komite urusan fiskal dari Organization for Economic Cooperation and Development (OECD) menyebutkan tiga karakter penghindaran pajak yaitu:

1. Adanya unsur artifisial dimana berbagai peraturan seolah-olah terdapat di dalamya padahal tidak dan ini dilakukan karena ketiadaan faktor pajak.

2. Memanfaatkan loopholes dari undang-undang atau menerapkan ketentuan-ketentuan legal untuk berbagai tujuan, padahal bukan itu yang sebenarnya dimaksudkan oleh pembuat undangundang.

3. Para konsultan menunjukkan alat atau cara untuk melakukan penghindaran pajak dengan syarat wajib pajak menjaga serahasia mungkin (Cahyono dkk., 2016).

Cahyono dkk (2016) menyatakan bahwa penghindaran pajak dapat dilakukan dengan berbagai cara diantaranya sebagai berikut:

1. Memindahkan subjek pajak dan/atau objek pajak ke negara-negara yang memberikan perlakukan pajak khusus atau keringanan pajak (tax haven country) atas suatu jenis penghasilan (substantive tax planning)

2. Usaha penghindaran pajak dengan mempertahankan substansi ekonomi dari transaksi melalui pemilihan formal yang memberikan beban pajak yang paling rendah (formal tax planning)

Banyak penelitian tentang penghindaran pajak yang telah dilakukan dan lebih melihat pada karakteristik di level perusahaan seperti ukuran perusahaan, skala ekonomi melalui kegiatan operasi di luar negeri, perencanaan pajak dan faktor lain yang mempengaruhi tindakan penghindaran pajak, sehingga penghindaraan pajak telah diukur dengan berbagai cara. Penelitian sebelumnya tentang penghindaran pajak secara sistematis berhubungan dengan atribut tertentu dari persuahaan, termasuk profitabilitas, operasi perusahaan di luar negeri, jumlah aset tidak berwujud, pengeluaran penelitian dan pengembangan, leverage dan lainnya.

Dyreng et al. (2010) melakukan penelitian untuk menguji apakah jajaran eksekutif atau top management memiliki dampak terhadap penghindaran pajak di perusahaannya. Dengan menggunakan eksekutif yang berpindah perusahaan, hasil penelitiannya menunjukkan bahwa secara individual eksekutif memiliki peran yang signifikan dalam menentukan level penghindaran pajak yang akan diambil. Hasil ini menunjukkan bahwa masingmasing eksekutif secara individu memiliki kecenderungan yang berbeda terhadap penghindaran pajak dan kecenderungan ini tidak dapat dijelaskan melalui karakteristik perusahaan.

\section{Strategi Bisnis}

Secara umum, terdapat tiga level strategi yang banyak diterapkan oleh perusahaan adalah strategi level korporat, strategi level unit bisnis atau strategi bersaing dan strategi level fungsional. Strategi level korporat berkaitan dengan penentuan keputusan akan menjadi apa perusahaan dan seperti apa bisnisnya, dan terdiri dari tiga masalah utama yaitu arah strategi, strategi portofolio dan strategi perusahaan induk. Strategi level unit bisnis berkaitan dengan bagaimana perusahaan bersaing dalam masing-masing aktivitas dan berusaha untuk mencapai keunggulan kompetitifnya dibandingkan dengan pesaing. Sedangkan strategi level fungsional atau operasional berhubungan dengan strategi perusahaan yang berkaitan dengan berbagai fungsi atau aktivitas operasional seperti rekrutmen, pemasaran, dan distribusi. 
Konsep strategi Miles dan Snow termasuk konsep yang paling banyak digunakan dalam mengklasifikasikan strategi yang diterapkan oleh perusahaan. Miles \& Snow (1978) menyatakan bahwa strategi merupakan aglomerasi keputusan di mana strategic business unit (SBU) menyelaraskan proses manajerial (termasuk kapabilitas) dengan lingkungannya. Terdapat empat jenis strategi yaitu Prospector-Analyzer-Defender-Reactor (PADR). Prospector haruslah inovatif dalam teknologi dan mencari pasar-pasar baru, Analyzer cenderung menyukai second-but-better strategy, Defender lebih ke arah engineering-oriented dan berfokus pada pemantapan segmen pasar yang relatif stabil, dan Reactor cenderung tidak memiliki strategi yang stabil dan sangat responsif terhadap perubahan lingkungan (Tjahjad, 2011)

Miles dan Snow (1978) menyatakan terdapat tiga tipologi strategi yang utama yaitu

1. Defender atau bertahan, yang memiliki karakteristik menutup sebagian dari total pasar dalam rangka menciptakan wilayah pasar yang stabil, sehingga mereka cenderung agresif untuk mencegah pesaing masuk ke lahan mereka dengan fokus pada harga yang kompetitif atau produk yang berkualitas tinggi. Defender juga fokus pada pasar yang sempit namun kuat, produknya tidak mengikuti tren namun memiliki pasar yang kuat, teknologi yang stabil karena produknya tidak mengikuti tren sehingga fokus pada biaya rendah, meminimalisasi tekanan risiko dan ketidakpastian, turnover karyawan rendah, fokus menjaga stabilitas organisasi dan operasional serta tidak agresif mengejar kesempatan baru.

2. Prospector, yang memiliki ciri-ciri berkebalikan dengan defender. Lingkungan yang dihadapi lebih dinamis dibandingkan organisasi lain dalam industri yang sama. Fokus utamanya adalah bagaimana menemukan dan memanfaatkan secara maksimal produk, wilayah pasar serta kesempatan baru. Sehingga prospector mengalokasikan, mengembangkan serta mempertahankan kapasitas mereka dalam jumlah besar pada aktivitas mencari lingkungan, segmen dan wilayah pemasaran baru, menciptakan peluang serta produk baru. Prospector cenderung lebih menyukai adanya perubahan dan ketidakpastian dibandingkan defender, karena memiliki fleksibilitas yang tinggi pada teknologi dan sistem administrasi organisasi menyesuaikan dengan produk/jasa baru yang mereka ciptakan.

3. Analyzer, adalah strategi yang merupakan gabungan dari prospector dan defender, yaitu strategi yang meminimalkan risiko dan memaksimalkan kesempatan untuk meraih laba. Analyzer menggabungkan kelebihan dari defender dan prospector menjadi satu strategi. Strategi ini berfokus pada mencari lokasi baru juga fokus untuk menemukan produk guna membidik konsumen baru dengan mengikuti atau menirukan keberhasilan prospector, analyzer juga fokus mempertahankan produk dan konsumen yang telah ada yang merupakan sumber utama pendapatannya. Sehingga analyzer menerapkan dualisme teknologi yaitu untuk memenuhi kebutuhan fleksibilitas dan stabilitas.

Higgins et al. (2015) menyatakan bahwa pengaruh strategi bisnis terhadap perilaku penghindaran pajak tergantung pada karakteristik masing-masing tipe strategi (misalnya fokus strategi, toleransi terhadap risiko dan struktur organisasi) dalam mempengaruhi biaya dan manfaat dari perencanaan pajak yang dilakukan. Terdapat 3 hal utama yang membedakan masing-masing jenis strategi yaitu sebagai berikut:

1. Strategi Dasar, defender akan fokus pada strategi untuk meminimalisasi biaya, sedangkan prospector akan fokus pada inovasi untuk menciptakan produk dan pasar baru.

2. Kesempatan, prospector memiliki kesempatan untuk melakukan perencanaan pajak yang muncul dari fokus mereka dalam memasuki area dan produk baru sebagai respon dari perubahaan yang sifatnya tetap. Defender tidak secara agresif mencari kesempatan baru dan memiliki operasi yang lebih stabil. Sehingga dengan demikian prospector memiliki kesempatan untuk menghindari pajak dibandingkan defender.

3. Produk dan biaya reputasi, produk yang dihasilkan defender cenderung memiliki produk substitusi yang layak. Sehingga defender lebih fokus pada biaya untuk mempertahankan reputasi daripada kehilangan pelanggan karena tindakan agresif dalam penghindaran pajak yang dapat diketahui oleh publik (Hanlon \& Slemrod, 2009). Sedangkan prospector tidak melakukan hal yang sama karena produk mereka cenderung unik dan tidak memiliki barang substitusi yang layak. Sehingga prospector tidak mementingkan biaya reputasi dan dapat melakukan penghindaran pajak yang lebih banyak dari pada defender sehingga prospector melakukan dengan cara yang lebih agresif.

Dyreng et al. (2010) melakukan penelitian untuk melihat pengaruh CEO terhadap penghindaran pajak. Secara umum, sebagian dari CEO adalah bukan orang 
yang ahli dalam perpajakan, sebagian dari CEO tidak ingin memahami strategi pajak, mereka ingin memahami kondisi persaingan industrinya dan kemungkinan ekspansi untuk meningkatkan skala operasional perusahaan. Sehingga, hal ini menjadi sangat beralasan bahwa CEO dapat mempengaruhi strategi operasional dan keuangan perusahaan, dan mungkin tidak terlalu banyak pada kegiatan yang berkaitan dengan penghindaran pajak. Meskipun demikian CEO dapat mempengaruhi penghindaran pajak melalui "tone at the top" atau irama di level atas yang berkaitan dengan kegiatan pajak perusahaan. Misalnya CEO mungkin mengubah penekanan pada fungsi perusahaan yang berbeda misalnya pemasaran, operasi, utang, pajak dan mengalokasikan sumberdaya untuk merekrut konsultan yang berbeda baik dari dalam maupun luar perusahaan. Irama ini dapat mempengaruhi insentif yang diberikan kepada para karyawan di bagian pajak yang ada di dalam perusahaan.

Higgins et al. (2015) melakukan penelitian untuk melihat hubungan strategi yang dipilih oleh perusahaan dengan penghindaran pajak yang dilakukan oleh perusahaan. Hasil penelitiannya menunjukkan bahwa prospector cenderung lebih melakukan penghindaran pajak dibandingkan defender. Prospector cenderung menempatkan operasinya di luar negeri di negara-negara dengan tarif pajak yang lebih rendah. Higgins et al. (2015) menyatakan bahwa strategi yang dipilih oleh perusahaan tidak hanya mempengaruhi tingkat penghindaran pajak yang dilakukan namun juga tingkat agresivitas pajak yang dilakukan oleh perusahaan. Perusahaan yang beroperasi pada lingkungan yang kompetitif cenderung melakukan aktivitas penghindaran pajak yang lebih banyak. Hasil penelitian yang dilakukan oleh Cai \& Liu (2009) menemukan bukti bahwa tingkat kompetisi yang lebih tinggi meningkatkan usaha perusahaan untuk menyembunyikan laba untuk menghindari pajak.

Berdasarkan uraian tersebut, defender dan prospector memiliki atribut kompetisi yang mendorong mereka untuk lebih atau kurang dalam melakukan penghindaran pajak. Meskipun defender cenderung meminimalkan biaya, namun mereka memiliki kesempatan yang lebih sedikit untuk melakukan penghindaran pajak, biaya yang lebih besar berhubungan dengan perencanaan pajak yang agresif, dan menghindari risiko. Sedangkan prospector tidak fokus pada biaya, namun memiliki kesempatan yang besar untuk melakukan perencanaan pajak, biaya yang lebih rendah berhubungan dengan perencanaan pajak yang agresif dan tidak menghindari risiko. Sehingga dapat diajukan hipotesis penelitian sebagai berikut:

$\mathrm{H}_{1}$ : Prospector melakukan penghindaran pajak yang lebih tinggi dibandingkan defender

Penghindaran pajak selalu diartikan sebagai kegiatan legal. Namun pertanyaan yang saat ini muncul adalah apakah penghindaran pajak atau tax avoidance selalu legal. Penghindaran pajak dapat saja dikategorikan sebagai kegiatan ilegal apabila transaksi yang dilakukan semata-mata untuk tujuan penghindaran pajak atau transaksi tersebut tidak mempunyai usaha yang baik. Penghindaran pajak dilakukan sebagai akibat dari suatu kesalahan alokasi yang terjadi di dunia nyata, kemerosotan etika bisnis, hilangnya independensi auditor dan inteferensi dengan suatu sistem kendali. Di beberapa negara penghindaran pajak dibedakan menjadi penghindaran yang diperbolehkan dan yang tidak diperbolehkan. Penghindaran pajak yang tidak diperbolehkan ini mengarah kepada agresivitas pajak yang digunakan dalam penelitian ini.

Jika tujuan dari perencanaan pajak adalah untuk merekayasan agar beban pajak dapat ditekan serencah mungkin dengan memanfaatkan peraturan yang ada tetapi berbeda dengan tujuan pembuat undangundang, maka perencanaan pajak ini sama dengan penghindaran pajak yang tidak dapat diterima dan mengarah ke pajak agresif (Cahyono et al., 2016). Perencanaan pajak adalah proses pengendalian tindakan agar terhindar dari konsekuensi pengenaan pajak yang tidak dikehendaki. Sedangkan agresivitas pajak adalah kegiatan yang lebih spesifik, yaitu mencakup kegiatan yang tujuan utamanya adalah menurunkan kewajiban pajak perusahaan. Bukti empiris saat ini menunjukkan bahwa agresivitas pajak lebih merasuk dalam tata kelola perusahaan yang lemah (Kuriah \& Asyik, 2016).

Strategi perusahaan yang dipilih dapat berdampak pada cara perusahaan dalam mempertahankan reputasinya di depan publik. Defender akan cenderung lebih berupaya untuk mempertahankan reputasinya. Jika sebuah perusahaan dipandang sebagai penghindar pajak, maka perusahaan tersebut dianggap tidak membayar pajak secara fair kepada pemerintah untuk membantu membiayai barang publik masyarakat. Kekurangan penerimaan pajak akan menghasilkan permusuhan, rusaknya reputasi bagi masyarakat. Pada akhirnya agresivitas pajak akan menghasilkan kerugian bagi masyarakat. Sehingga agresivitas pajak seharusnya dianggap sebagai tindakan tidak bertanggung jawab secara sosial dan merupakan aktivitas tidak terlegitimasi (Kuriah \& Asyik, 2016). 
Terkait dengan strategi bisnis yang dipilih oleh perusahaan, prospector cenderung lebih melakukan tindakan pajak agresif dibandingkan defender, defender lebih cenderung menghindari risiko dan ketidakpastian dengan melakukan tindakan pajak yang agresif. Sehingga prospector mengambil risiko dan siap untuk menghadapi hasil yang tidak pasti dari strategi penghindaran pajak yang agresif (Higgins et al., 2015). Sehingga dapat diajukan hipotesis penelitian:

$\mathrm{H}_{2}$ : Prospector melakukan agresivitas pajak yang lebih tinggi dibandingkan defender

\section{Metode Penelitian}

\section{Populasi dan sampel}

Populasi menunjukkan keseluruhan dari objek penelitian. Populasi dari penelitian ini adalah seluruh perusahaan publik yang terdaftar di Bursa Efek Indonesia (BEI). Sedangkan sampel adalah himpunan objek pengamatan yang dipilih dari populasi. Sampel penelitian ini dipilih dengan menggunakan metode purposive sampling yaitu pemilihan sampel dengan kriteria tertentu. Adapun kriteria yang digunakan adalah perusahaan manufaktur yang terdaftar di BEI tahun hingga tahun 2016, perusahaan menerbitkan laporan keuangan secara lengkap selama periode pengamatan, tersedia data-data secara lengkap sesuai dengan variabel penelitian dan perusahaan tidak delisting selama periode pengamatan.

\section{Definisi operasional}

\section{Penghindaran Pajak}

Penghindaran pajak merupakan perencanaan pajak melalui cara legal yaitu memanfaatkan celah aturan pajak untuk meminimalkan biaya pajak perusahaan. Untuk mengukur besarnya tax avoidance, penelitian ini menggunakan tiga proksi yang digunakan oleh Higgins et al. (2015) yaitu:

a. Book effective tax rate (Book ETR) yang menggambarkan persentase total beban pajak penghasilan yang dibayarkan perusahaan dari seluruh pendapatan sebelum pajak yang diterima dan/atau diperoleh perusahaan.

b. Cash effective tax rate (Cash ETR) yang menggambarkan persentase total uang yang dikeluarkan untuk membayar pajak penghasilan yang dibayarkan perusahaan dari seluruh pendapatan sebelum pajak yang diterima dan/atau diperoleh perusahaan. c. Permanent book-tax difference (PERMDIFF) merupakan nilai residu dari komponen beda permanen yang dihitung dengan mengurangkan book-tax difference dengan temporary book-tax difference dibagi dengan total aset.

\section{Agresivitas Pajak}

Sesuai dengan penelitian yang dilakukan Higgins et al. (2015) untuk mengukur besarnya agresivitas pajak yang dilakukan oleh perusahaan, penelitian ini menggunakan tax haven (HAVENFIRM) sebagai indikator terhadap agresivitas pajak yang dilakukan oleh perusahaan dengan memindahkan subjek pajak dan/atau objek pajak ke negaranegara yang memberikan perlakukan pajak khusus atau keringanan pajak. Variabel ini diukur dengan variabel dummy jika perusahaan beroperasi pada satu atau lebih negara surga pajak, jika iya maka bernilai 1 dan 0 jika sebaliknya.

3. Strategi Bisnis

Strategi bisnis merupakan strategi yang dipilih perusahaan untuk bersaing dan beradaptasi menghadapi lingkungan yang kompetitif. Untuk menentukan strategi yang digunakan oleh setiap perusahaan, digunakan komposit ukuran strategi yang terdiri dari enam ukuran yang dikembangkan oleh Bentley et al. (2013) yaitu:

a. Ratio of research and development to sales (RDS), rasio ini digunakan untuk mengukur kemampuan perusahaan untuk mengembangkan produk baru dan dihitung dengan membagi biaya riset dan pengembangan dengan total penjualan.

b. Ratio of employee to sales (EMPS), rasio ini digunakan untuk mengukur kemampuan perusahaan untuk memproduksi dan mendistribusikan barang secara efisien. Rasio ini dihitung dengan membagi jumlah pegawai dengan total penjualan.

c. Geometric mean of market value of asset (GMVA), yang digunakan untuk mengukur pertumbuhan historis atau kesempatan investasi yang diukur dengan logaritma dari nilai pasar aset.

d. Employee turnover ( $\sigma$ EMP), yang digunakan untuk mengukur stabilitas organisasi suatu perusahaan dari total karyawan dihitung dari standar devisasi total jumlah karyawan.

e. Marketing to sales, yang digunakan untuk mengukur fokus perusahaan dalam mengeksploitasi produk dan jasa baru. Rasio ini dihitung dengan menjumlahkan biaya 
penjualan, administrasi dan umum dibagi dengan total penjualan.

f. Capital intensity (CAP), merupakan ukuran dari komitmen perusahaan atas efisiensi teknologi. Rasio ini dihitung dengan membagi net plant, property and equipment dengan total aset.

Seluruh rasio ini dihitung rata-rata bergeraknya selama 5 tahun dengan periode sebelumnya kemudian dibuat peringkat berdasarkan quintile, dengan ketentuan quintile tertinggi diberi nilai 5 , di posisi selanjutnya diberi nilai 4 dan seterusnya (kecuali untuk CAP yang menggunakan urutan terbalik). Berdasarkan skor tersebut nilai tiap-tiap perusahaan untuk enam ukuran per tahun dijumlah, sehingga akan diperoleh nilai maksimum 30 yang merupakan indikator dari tipe strategi prospector dan nilai minimum 6 yang merupakan indikator dari tipe strategi defender. Bentley et al. (2013) menyatakan bahwa perusahaan dapat dikategorikan sebagai defender jika rata-rata peringkat perusahaan untuk 6 ukuran variabel berada pada quintile paling rendah (nilai 1 atau 2) atau memiliki total skor pada range minimal 6 sampai dengan 12. Sebaliknya perusahaan akan dikategorikan sebagai prospector jika rata-rata peringkat perusahaan untuk 6 ukuran variabel berada pada quintile paling tinggi (bernilai 5 atau 4). Sehingga untuk perusahaan dengan total skor pada range 24 sampai 30 dikategorikan sebagai perusahaan prospector. Jika terdapat perusahaan yang memiliki skor nilai di luar range tersebut yaitu pada range 1323 maka akan dikategorikan sebagai analyzer.

4. Variabel kontrol

a. Ukuran perusahaan (SIZE) diartikan sebagai sebuah skala untuk mengkategorikan sebuah perusahaan sebagai perusahaan besar atau kecil. Ukuran perusahaan dimasukkan sebagai variabel kontrol untuk membedakan secara kuantitatif antara perusahaan besar (large firm) dengan perusahaan kecil (small firm) yang dapat mempengaruhi kemampuan manajemen untuk mengoperasikan perusahaan dalam berbagai situasi dan kondisi yang dihadapinya. Selain itu ukuran perusahaan juga perlu dibedakan untuk mengontrol adanya motivasi politis dalam penghindaran pajak (perusahaan tidak menghindari pajak dalam jumlah tinggi untuk menghindari sorotan publik atau aturan dari pemerintah/fiskus), diukur dengan logaritma natural dari aset total. b. Profitabilitas perusahaan (return on assets/ROA), merupakan rasio profitabilitas untuk mengukur kemampuan perusahaan menghasilkan keuntungan dari aktivitas bisnisnya. Kinerja perusahaan perlu dipertimbangkan karena dapat mempengaruhi besar kecilnya pajak dari tahun ke tahun.

c. Umur perusahaan (AGE), yang menggambarkan kedewasaan (maturity) perusahaan dengan mengukur lamanya perusahaan beroperasi dalam tahun. Hal ini dilakukan untuk mengontrol perbedaan pengalaman perusahaan dalam menghindari pajak.

d. Leverage (LEV) adalah kemampuan perusahaan untuk menyelesaikan semua kewajiban jangka panjang. Perusahaan yang menggunakan hutang akan menimbulkan adanya bunga yang harus dibayar. UndangUndang Nomor 36 tahun 2008 pasal 6 ayat 1 huruf 3 tentang Pajak Penghasilan, bunga pinjaman merupakan biaya yang dapat dikurangkan terhadap penghasilan kena pajak. Beban bunga ini dapat menyebabkan laba kena pajak perusahaan menjadi berkurang yang pada akhirnya akan mengurangi jumlah pajak yang harus dibayar perusahaan. Rasio ini dihitung dengan membagi utang jangka panjang dengan total aset.

e. Intangible assets (INTAN) adalah besarnya jumlah aset tidak berwujud yang dimiliki oleh perusahaan yang dapat mempengaruhi tingkat pajak. Rasio ini diukur dengan membagi aset tidak berwujud dengan total aset .

f. Intensitas persediaan (INVENTORY), memberikan gambangan jumlah persediaan perusahaan yang dibutuhkan perusahaan untuk beroperasi. Rasio ini juga menunjukkan keputusan alokasi komposisi aset pada persediaan yang dapat mempengaruhi tingkat pajak. Rasio ini diukur dengan membagi total persediaan dengan total aset.

\section{Pengujian hipotesis}

Untuk menguji $\mathrm{H}_{1}$ digunakan independent sample t-test, pengujian ini dilakukan untuk melihat perbedaan antara dua kelompok subyek yang independen yaitu kelompok perusahaan dengan strategi prospector dan defender. Kriteria pengambilan keputusan dalam pengujian ini adalah dengan melihat besarnya tax avoidance pada kedua kelompok apakah prospector memiliki nilai yang 
lebih besar dibandingkan defender. Jika lebih besar dan memiliki nilai signifikan $<0,05$ maka $\mathrm{H}_{1}$ didukung, dan sebaliknya. Sedangkan untuk $\mathrm{H}_{2}$ yang melihat perbedaan besarnya agresivitas pajak pada prospector dan defender digunakan uji non parametris yaitu Mann Whitney $U$ test karena variabel dependennya merupakan variabel non metrik (nominal). $\mathrm{H}_{2}$ diterima jika nilai Asymp sig. $<0,05$ dan besarnya agresivitas pajak pada prospector memiliki nilai yang lebih besar dibandingkan defender.

\section{Pembahasan}

Sampel penelitian ini adalah perusahaan manufaktur yang telah terdaftar di BEI sejak 2010 hingga 2016. Berdasarkan kriteria pemilihan sampel yang telah ditentukan, diperoleh sampel penelitian sebagai berikut:

Tabel 1

Jumlah Sampel Penelitian

\begin{tabular}{lc}
\hline \multicolumn{1}{c}{ Keterangan } & Jumlah perusahaan \\
\hline Jumlah perusahaan manufaktur & 144 \\
Listing setelah tahun 2010 & 10 \\
Data perusahaan tidak lengkap & 30 \\
Jumlah sampel penelitian & 104 \\
Tahun & 3 \\
\hline Jumlah $n$ & 312 \\
\hline
\end{tabular}

Berikut ini disajikan statistik dekriptif dari data yang digunakan dalam penelitian ini adalah sebagai berikut:

Tabel 2

Hasil Statistik Deskriptif

\begin{tabular}{lrrrr}
\hline & Minimum & Maximum & \multicolumn{1}{c}{ Mean } & $\begin{array}{c}\text { Std. } \\
\text { Deviation }\end{array}$ \\
\hline BOOKETR & -15.280000 & 5.560000 & .05330128 & 1.148177221 \\
CASHETR & -6.970000 & 8.180000 & .21381410 & 1.182745405 \\
PERMDIF & -.204857 & .055430 & -.00246298 & .021857318 \\
SIZE & 10.602934 & 14.418061 & 12.37925969 & .698542493 \\
ROA & -.981310 & 3.496220 & .08146846 & .229899108 \\
AGE & .000000 & 85.000000 & 36.33653846 & 12.370702796 \\
LEV & .002552 & 4.517682 & .18900142 & .333874023 \\
INTAN & .000000 & .168024 & .00594939 & .018680447 \\
INVENTORY & .000000 & .614207 & .20057484 & .116576837 \\
Valid N & & & & \\
(listwise) & & & & \\
\hline
\end{tabular}

Berdasarkan jumlah sampel yang telah ditentukan, selanjutnya dilakukan identifikasi strategi dari masing-masing perusahaan. Dengan menggunakan data dari tahun 2010-2016 diketahui terdapat 8,98\% perusahaan atau sebanyak 28 perusahaan merupakan perusahaan yang menerapkan strategi prospector, sejumlah $45,55 \%$ atau sebanyak 139 perusahaan menggunakan strategi defender dan sisanya yaitu
$46,47 \%$ atau 145 perusahaan menerapkan strategi analyzer.

Tabel 3

Pengelompokan Strategi

\begin{tabular}{lcc}
\hline \multicolumn{1}{c}{ Jenis Strategi } & Jumlah Perusahaan & $\%$ \\
\hline Defender & 139 & 45,55 \\
Analyzer & 145 & 46,47 \\
Prospector & 28 & 8,98 \\
\hline Jumlah & 312 & 100 \\
\hline
\end{tabular}

Pengaruh variabel kontrol terhadap penghindaran pajak

Hasil pengujian terhadap variabel kontrol menunjukkan bahwa terdapat perbedaan yang signifikan pada ukuran perusahaan dan jumlah intagible assets yang dimiliki oleh prospector dan defender. Umumnya prospector merupakan perusahaan yang lebih besar dan memiliki intagibles assets yang lebih besar dari pada defender. Besar kecilnya suatu perusahaan akan mempengaruhi tingkat tindakan penghindaran yang dilakukan perusahaan. Tax avoidance merupakan tindakan yang legal dan tidak melanggar hukum, namun dilakukan dengan melakukan penghematan dengan cara mengatur tindakan untuk menghindari pengenaan pajak melalui pengendalian laporan keuangan dan data pendukung lainnya, sehingga terhindar dari pengenaan pajak yang lebih besar atau sama sekali tidak kena pajak. Perusahaan dengan kategori besar dapat membayar lebih banyak ahli pajak untuk mengelola pajak. Perusahaan besar akan mampu membayar lebih banyak ahli untuk mengelola pajaknya. Umumnya di perusahaan yang besar jenis transaksinya semakin variatif dan kompleks yang memungkinkan perusahaan untuk memanfaatkan celah-celah peraturan perpajakan untuk melakukan penghindaran pajak (Kuriah \& Asik, 2016).

Tabel 4

Hasil Pengujian Variabel Kontrol

\begin{tabular}{llrrc}
\hline \multicolumn{1}{c}{ Variabel } & Strategi & Mean & $\begin{array}{c}\text { Mean } \\
\text { Difference }\end{array}$ & Sig \\
\hline Ukuran & Defender & 12,2157 & $-0,6083$ & 0,002 \\
Perusahaan & Prospector & 12,8239 & & \\
Profitabilitas & Defender & 0,06621 & $-0,0298$ & 0,147 \\
& Prospector & 0,0960 & & \\
Umur & Defender & 35,9424 & 1,4067 & 0,645 \\
Perusahaan & Prospector & 34,5357 & & \\
Leverage & Defender & 0,1547 & 0,0270 & 0,248 \\
& Prospector & 0,1277 & & \\
Intagible & Defender & 0,0030 & $-0,0272$ & 0,006 \\
Assets & Prospector & 0.0301 & & \\
Intensitas & Defender & 0,1958 & 0,0046 & 0,844 \\
Persediaan & Prospector & 0,1912 & & \\
\hline
\end{tabular}




\section{Pengujian $H_{I}$}

Dalam penelitian ini $\mathrm{H}_{1}$ menyatakan bahwa perusahaan dengan strategi prospector cenderung melakukan penghindaran pajak yang lebih tinggi dibandingkan perusahaan dengan strategi defender. Untuk melakukan pengujian terhadap $\mathrm{H}_{1}$ uji independent sample t-test dengan hasil sebagai berikut:

Tabel 5

Hasl Pengujian H1

\begin{tabular}{|c|c|c|c|c|}
\hline Variabel & Strategi & Mean & $\begin{array}{c}\text { Mean } \\
\text { Difference }\end{array}$ & Sig \\
\hline Book ETR & $\begin{array}{l}\text { Defender } \\
\text { Prospector }\end{array}$ & $\begin{array}{r}-0.0669 \\
0.2757\end{array}$ & $-0,3426$ & 0,015 \\
\hline Cash ETR & $\begin{array}{l}\text { Defender } \\
\text { Prospector }\end{array}$ & $\begin{array}{l}0,1307 \\
0,4325\end{array}$ & -0.3018 & 0,083 \\
\hline $\begin{array}{l}\text { Permanent } \\
\text { book-tax } \\
\text { Different }\end{array}$ & $\begin{array}{l}\text { Defender } \\
\text { Prospector }\end{array}$ & $\begin{array}{r}-0,0019 \\
0,0018\end{array}$ & $-0,0037$ & 0,169 \\
\hline
\end{tabular}

Berdasarkan hasil pengujian yang telah dilakukan diketahui bahwa pengaruh strategi terhadap penghindaran pajak yang diukur berdasarkan book ETR dan cash ETR menunjukkan hasil yang signifikan sehingga dapat disimpulkan $\mathrm{H}_{1}$ didukung. Hasil penelitian ini mendukung temuan Miles dan Snow (1978; 2003); Higgins et al. (2015) dan Kuriah \& Asik (2016) yang menyatakan bahwa perusahaan dengan strategi prospector lebih cenderung melakukan penghindaran pajak dibandingkan defender. Hal ini menguatkan bukti adanya hubungan kuat antara penghindaran pajak dengan tipologi strategi bahwa prospector memiliki peluang lebih besar untuk melakukan penghindaran pajak. Perusahaan dengan strategi prospector umumnya lebih dapat mengantisipasi risiko yang dihadapi dan juga memiliki persiapan yang baik untuk menghadapi ketidakpastian yang diakibatkan oleh tindakan penghindaran pajak yang dilakukan.

\section{Pengujian $\mathrm{H}_{2}$}

Penelitian ini menyatakan bahwa perusahaan dengan strategi prospector melakukan agresivitas pajak yang lebih tinggi dibandingkan defender. Dalam penelitian ini agresivitas pajak diukur dengan ada atau tidaknya aktivitas investasi dalam bentuk anak perusahaan di negara-negara dengan tarif pajak yang lebih rendah atau sering disebut dengan istilah tax haven. Dari seluruh sampel penelitian, diketahui terdapat 75 perusahaan atau $24 \%$ dari sampel yang melakukan investasi pada tax haven. Berikut ini adalah rincian perusahaan berdasarkan ada tidaknya investasi pada negara tax haven:

Tabel 6

Jumlah Investasi di Tax Haven

\begin{tabular}{ccc}
\hline Keterangan & Jumlah & \% \\
\hline Tidak ada & 237 & 76 \\
Ada & 75 & 24 \\
\hline Jumlah & 312 & 100 \\
\hline
\end{tabular}

Selanjutnya untuk melakukan pengujian $\mathrm{H}_{2}$ dilakukan uji beda dengan menggunakan uji Mann Whitney $U$ test untuk membandingkan tindakan agresivitas pajak oleh perusahaan prospector dan defender. Hasil pengujian menunjukkan bahwa tidak terdapat perbedaan yang signifikan tingkat agresivitas pajak pada kedua kelompok perusahaan sehingga $\mathrm{H}_{2}$ tidak dapat didukung. Namun sejalan dengan landasan teori bahwa prospector memiliki agresivitas pajak yang lebih tinggi dibandingkan defender sebagaimana disajikan pada tabel berikut:

Tabel 7 Hasil Pengujian H2

\begin{tabular}{cccc}
\hline Strategi & Mean & Mean Difference & Sig \\
\hline Defender & 0,21 & $-0,029$ & 0,613 \\
Prospector & 0,24 & & \\
\hline
\end{tabular}

Hasil analisis lebih lanjut terhadap sampel yang melakukan investasi pada negara-negara tax haven diperoleh data bahwa sebagian besar dari perusahaan tersebut memiliki strategi defender $(69,33 \%)$ dan disusul oleh perusahaan dengan strategi analyzer (18\%) dan sisanya adalah prospector sebagaimana disajikan secara lengkap pada tabel berikut:

Tabel 8

Strategi pada Perusahaan Tax Haven

\begin{tabular}{rcc}
\hline Strategi & Jumlah & \% \\
\hline Defender & 52 & 69,33 \\
Analyzer & 18 & 24 \\
Prospector & 5 & 6,67 \\
\hline Jumlah & 75 & 100 \\
\hline
\end{tabular}

Desai et al. (2006) menyatakan bahwa perusahaan dengan tingkat penjualan yang tinggi kepada kolega di luar negeri lebih cenderung memiliki fasilitas tax haven. Hal ini konsisten dengan usaha untuk memindahkan pendapatan kena pajaknya dari negara asal ke negara tax haven dan dengan memanfaatkan afiliasi di tax haven untuk menunda pajak penghasilan yang dikenakan negara asal dengan melaporkan bahwa penghasilan tersebut diperoleh dari afiliasi di luar negeri. Hasil penelitian ini menunjukkan bahwa pada perusahaan yang memfokuskan usahanya pada 
penghematan biaya cenderung lebih banyak melakukan investasi pada tax haven. Melalui afiliasi pada tax haven maka akan diperoleh fasilitas berupa pemindahan penghasilan kena pajak dari negara dengan tarif pajak yang tinggi ke negara dengan tarif lebih rendah serta mengurangi beban dengan memindahkan pajak penghasilan dari negara asal ke pajak negara lain dengan tarif yang lebih rendah.

Faradiza (2018) dalam penelitiannya menyatakan bahwa dampak dari strategi yang diterapkan oleh perusahaan sangat dipengaruhi oleh intensitas persaingan yang dihadapi oleh perusahaan. Tingkat persaingan pada perusahaan manufaktur di Indonesia saat ini berada pada tingkat yang tinggi. Sehingga strategi yang tepat digunakan adalah defender yaitu perusahaan tetap berusaha tetap mengelola pasar yang aman dengan produk yang bersifat stabil. Pada tingkat persaingan yang tinggi maka strategi low-cost defender lebih tepat karena menekankan pada efisiensi biaya dan menekankan pada pentingnya penentuan biaya berdasarkan standar dan realisasi dari anggaran termasuk penghematan biaya pajak dengan melakukan investasi di luar negeri terutama di negara tax haven.

\section{Kesimpulan, Keterbatasan dan Saran}

Berdasarkan penelitian yang telah dilakukan maka dapat disimpulkan bahwa pemilihan strategi bisnis yang dipilih perusahaan berdampak pada aktivitas pajak yang dilakukan oleh perusahaan. Dalam hal penghindaran pajak perusahaan yang menerapkan strategi sebagai prospektor lebih cenderung melakukan tindakan penghindaran pajak dibandingkan perusahaan dengan strategi defender. Sedangkan dalam hal agresivitas pajak yang diukur dengan ada tidaknya investasi perusahaan pada negara tax haven dalam bentuk anak perusahaan diperoleh kesimpulan bahwa strategi tidak berdampak signifikan pada tindakan tersebut. Namun demikian berdasarkan data yang diperoleh bahwa sebagian besar perusahaan yang melakukan tindakan agresivitas pajak menerapkan strategi bisnis sebagai defender.

Pada penelitian yang akan datang sebaiknya peneliti mempertimbangkan:

1. Untuk mengukur agresivitas pajak, perusahaan hanya melihat pada ada tidaknya investasi pada negara tax haven dalam bentuk anak perusahaan dan tidak mempertimbangkan aktivitas lainnya seperti penjualan yang dilakukan dengan afiliasi di negara tax haven dan transaksi lain dengan pihak-pihak yang memiliki hubungan istimewa. Sehingga penelitian yang akan datang dapat mempertimbangkan faktor tersebut sebagai ukuran dari agresivitas pajak.

2. Penelitian ini hanya fokus pada satu sektor usaha yaitu manufaktur. Penelitian yang akan datang dapat melakukan penelitian dengan membandingkan perilaku perusahaan dalam menghindari pajak pada berbagai sektor usaha.

\section{References}

Bentley, K. A., Omer, T. C., \& Sharp, N. Y. (2013). Business strategy, financial reporting irregularities, and audit effort. Contemporary Accounting Research, 30(2), 780-817. https://doi.org/10.1111/j.1911-3846.2012.01174.x

Cahyono, D. D., Andini, R., \& Raharjo, K. (2016). Pengaruh Komite Audit, Kepemilikan Institusional, Dewan Komisaris, Ukuran Perusahaan (Size), Leverage (DER) dan Profitabilitas (ROA) Terhadap Tindakan Penghindaran Pajak (Tax avoidance) Pada Perusahaan Perbankan yang Listing BEI Periode Tahun 2011 - 2013. Journal of Accounting, 2(2)

Cai, H. B., \& Liu, Q. (2009). Competition and Corporate Tax avoidance: Evidence from Chinese Industrial Firms. Economic Journal, 119(537), 764-795.

Desai, M. A., Foley, C. F., \& Hines, J. R. (2006). The demand for tax haven operations. Journal of Public Economics, 90(3), 513-531. https://doi.org/10.1016/j.jpubeco.2005.04.004.

Dyreng, S. D., Hanlon, M., \& Maydew, E. L. (2010). The effects of executives on corporate tax avoidance. Accounting Review, 85(4), 1163-1189. https://doi.org/10.2308/accr.2010.85.4.1163.

Faradiza, S. A. (2018). Kinerja Perusahaan Dan Keselarasan Strategi Dengan Intensitas Persaingan dan Kecanggihan Praktik Akuntansi Manajemen, 11(2), 223-244. https://doi.org/10.15408/akt.v11i2.8803.

Graham, J. R., Hanlon, M., Shevlin, T., \& Shroff, N. (2014). Incentives for Tax Planning and Avoidance: Evidence from the field. Accounting Review, 89(3), 991-1023. https://doi.org/10.2308/accr-50678.

Hanlon, M., \& Slemrod, J. (2009). What does tax aggressiveness signal? Evidence from stock price reactions to news about tax shelter involvement. Journal of Public Economics, 93(1-2), 126141. https://doi.org/10.1016/j.jpubeco.2008.09.004

Higgins, D., Omer, T. C., \& Phillips, J. D. (2015). The Influence of a Firm's Business Strategy on its Tax Aggressiveness. Contemporary Accounting Research, 32(2), 674-702. https://doi.org/10.1111/1911-3846.12087

Kuriah, H. L., \& Asyik, N. F. (2016). Pengaruh Karakteristik Perusahaan dan Corporate Social Responsibility Terhadap Agresivitas Pajak. Jurnal Ilmu Dan Riset Akuntansi, 5(3), 1-19.

Miles, R. E., Snow, C. C., Meyer, A. D., \& Coleman Jr., H. J. (1978). Organizational Strategy, Structure, and Process. The Academy of Management Review. https://doi.org/10.2307/257544

Tjahjad, B. (2011). Hubungan sistem manajemen risiko dengan ketidakpastian lingkungan dan strategi serta dampaknya terhadap kinerja organisasi. Majalah Ekonomi, XXI(2), 142-154. 